\title{
Incident of algae blooms of Lake Svyatozero (Karelia, Russia)
}

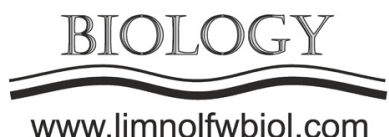

\author{
Makarova E.M.*, Fedorova V.S. \\ Northern Water Problems Institute of the Karelian Research Centre of the Russian Academy of Sciences Aleksander Nevsky Str., 50 \\ Petrozavodsk, Republic of Karelia, 185030, Russia
}

\begin{abstract}
The article presents results of the investigation of the littoral zone state in the northern part of Lake Svyatozero (Karelia) according to microbiological and phytoplankton indicators. We studied the causes of the appearance of a "bloom spot" in September 2019. The total abundance of bacteria was $6.42 \times 10^{6}$ cells $/ \mathrm{ml}$, the abundance of saprophytic bacteria growing at $22^{\circ} \mathrm{C}$ was $20.3 \times 10^{3}$ $\mathrm{CFU} / \mathrm{ml}$, saprophytic bacteria growing at $37^{\circ} \mathrm{C}$ was $1.74 \times 10^{3} \mathrm{CFU} / \mathrm{ml}$. The development of bacteria indicated that self-purification processes were completed. The total abundance of phytoplankton was $198712.5 \times 10^{3}$ cells/l, and the total biomass was $14.945 \mathrm{mg} / \mathrm{l}$. A total of 17 phytoplankton species were identified, 14 of which were ranked Cyanophyta $(96.7 \%$ of the total abundance and $99.8 \%$ of the total biomass). Microcystis aeruginosa inhibiting the development of bacterioplankton was found in the water. Blooming of blue-green algae was apparently due to secondary pollution of the water body following low water level, wind intensity, waterborne soil movement, and warm weather. During the study period, water from the littoral zone in the northern part of Lake Svyatozero was estimated as highly polluted with the quality class 4 and was characterized as a stopgap measure from mesotrophic to the eutrophic water body.
\end{abstract}

Keywords: eutrophic lake, algae blooms, phytoplankton, bacterioplankton, water quality assessment.

\section{Introduction}

In September 2019, extremely high phytoplankton bloom was detected in the littoral zone of the northern part of the lake. The aim of the research was to determine the causes of algae blooms and assess the quality of the water in the littoral zone of the lake using bacteria- and phytoplankton indicators.

\section{Material and methods}

Hydrobiological studies were conducted in accordance with general hydrobiology techniques (Metodika..., 1975; Kuznetsov and Dubinina, 1989). Trophic status, saprobity, and water quality assessment of the littoral zone of Lake Svyatozero were assessed according to Sladecek (1973), Romanenko (1985), Oksyuk et al. (1993), Barinova et al. (2006).

\section{Results and Discussion}

The total abundance (TA) of bacteria was $6.42 \times 10^{6} \mathrm{cell} / \mathrm{ml}$; the abundance of saprophytic bacteria (SB) was $20.3 \times 10^{3} \mathrm{CFU} / \mathrm{ml}$. The developmental character of littoral bacterioplankton is indicative of the polytrophic type of water body. Total bacterial count (TBC), being the indicator group of bacteria of anthropogenic pollution and allochthonous microbial flora, was $1.74 \times 10^{3} \mathrm{CFU} / \mathrm{ml}$. The ratio of SB to TBC was high (11.7), thus, indicating the completion of selfpurification processes. A share of SB in TA was $0.1 \%$ that implied the septic condition of the littoral zone.

The total abundance of phytoplankton was $198712.5 \times 10^{3}$ cells $/ 1$, and the total biomass was 14.945 $\mathrm{mg} / \mathrm{l}$. A total of 17 phytoplankton species was identified, of which 14 species ranked Cyanophyta $(96.7 \%$ of the total abundance and $99.8 \%$ of the total biomass), followed by one Chlorophyta, one Bacillariophyta and one Euglenophyta. The dominant species were Microcystis wesenbergii Komarek., Microcystis aeruginosa Kütz. (Elenk) f. aeruginosa, Woronochinia naegeliana (Ung.) Elenk. f. naegeliana, Microcystis flos-aquae Kirchn. Saprobity index (1.7) of littoral phytoplankton is indicative of the $\beta$-mesosaprobic type of water body according to biomass. Water quality was witness to a high level of pollution.

\section{Conclusions}

Due to the extremely high bloom of bluegreen algae, the abundance of bacterioplankton was suppressed. Microcystis aeruginosa Kütz. (Ellen) $f$. 
aeruginosa was detected in samples. It caused toxic effects on the development of bacterioplankton (Kopylov and Kosolapov, 2007). The bloom of bluegreen algae was probably related to the secondary pollution of the water body, with a low water level, the intensity of the wind-induced current, waterborne soil movement, and favourable weather conditions. The water from the littoral zone in the northern part of Lake Svyatozero was estimated as highly polluted with a quality class 4 .

\section{Acknowledgements}

The study was conducted under a state assignment granted to the Karelian Research Center of the Russian Academy of Sciences (Northern Water Problems Institute, KRC, RAS).

\section{References}

Barinova S.S., Medvedeva L.A., Anisimova O.V. 2006. Bioraznoobraziye vodorosley-indikatorov okruzhayushchey sredy [Diversity of algal indicators in environmental assessment]. Tel Aviv: Pilies Studio. (in Russian)

Kopylov A.I., Kosolapov D.B. 2007. Microbiological indicators of eutrophication of freshwater bodies. In: Mezhdunarodnaya Konferenciya "Bioindikatsiya v Monitoringe Presnovodnykh Ekosistem" [International Conference "Bioindication in Monitoring of Freshwater Eecosystems"], pp. 176-181. (in Russian)

Kuznetsov S.I., Dubinina G.A. 1989. Metody izucheniya vodnykh mikroorganizmov [Methods of study of aquatic organisms]. Moscow: Nauka. (in Russian)

Metodika izucheniya biogeotsenozov vnutrennikh vodoyemov [Methodology for the study of biogeocenoses of inland waters]. 1975. In: Mordukhay-Boltovskoy F.D. (Ed.). Moskow: Nauka. (in Russian)

Oksyuk O.P., Zhukinskiy V.N., Braginskii L.P. et al. 1993. Complex ecological classification of quality of the inland surface water. Gidrobiologicheskiy Zhurnal [Hydrobiological Journal] 2: 62-76. (in Russian)

Romanenko V.I. 1985. Mikrobiologicheskiye protsessy produktsii i destruktsii organicheskogo veshchestva vo vnutrennikh vodoyemakh [Microbiological processes of production and destruction of organic matter in inland waters]. Leningrad: Nauka. (in Russian)

Sladecek V. 1973. System of water quality from the biological point of view. Advances in Limnology 7: 1-218. DOI: 10.1002/iroh.19740590412 